\title{
VIII.-Perforate and Imperforate Brachiopoda.
}

By Thomas Davidson, F.R.S., F.G.S., etc.

(PLATE XIV.)

TN answer to the observations made by Professor King in the June number of your valuable Magazine, I am quite ready to admit that several very important points in connection with the shell-structure and interior arrangements of the Spiriferide have still to be determined, and I am always delighted when some new light can be thrown upon the subject.

No one has devoted as much time or shown a greater degree of ability in the careful examination of the shell-structure of the Brachiopoda than Dr. Carpenter has done; and I have no hesitation in reiterating that $I$ cannot doubt the trustworthiness and accuracy of his investigations. Dr. Carpenter has repeatedly shown the absolute necessity of thin sections viewed with adequate microscopic power; and it, therefore, surprises me, that Professor King should so often endeavour to throw discredit on that gentleman's observations, on the strength of surface-markings observed with a "handmagnifier."

Now, with reference to Spirifera cuspidata, Dr. Carpenter assures us that, after having carefully examined by the aid of first-rate instruments the well-preserved shells of several specimens, he found in them a total absence of perforations; but that a deceptive appearance of dots upon certain portions of the surface in some examples may have led. to the erroneous supposition that the shell had been pierced throughout by canals. Several statements in an interesting paper by $\mathrm{Mr}$. Meek, published in the Proceedings of the Academy of Natural Sciences of Philadelphia for December, 1865, made Dr. Carpenter desirous of re-investigating the subject; and consequently the shells of several American and British Spirifers, resembling in shape our well-known Spirifera cuspidata, were assembled and carefully examined. Dr. Carpenter publishes the results of his investigation in the July number of the Annals and Mag. of Nat. Hist. for the present year.

Some few years ago Professor Winchell discovered in the Carboniferous rocks or "Burlington Limestone" of Burlington, Iowa, a shell undistinguishable in exterior appearance from our British examples of Spirifera cuspidata, but which, from presenting certain peculiar interior arrangements, had led him to propose for that and similarly characterized shells the generic denomination of Syringothyris. ${ }^{1}$ Now, although Professor Winchell has stated that the shell of his genus is fibrous and impunctate in all conditions and under high powers, both Mr. Meek and Dr. Carpenter found very distinct perforations in large portions of the shell of Syringothyris typa forwarded to them by Professor Winchell himself. ${ }^{2}$

1 Proceedings of the Academy of Natural Sciences of Pbiladelphia, January, 1863.

2 Ser Notrces of Memoras, at the end of this article (p. 315), for Mr. F. B. Meek's observations on the shell-structure of Syringothyris. 
In 1863, as already stated, Professor Winchell describes (but does not figure) his genus as "a shell with an elongated hinge-line. Ventral valve with a mesial sinus, a very broad area, and a narrow triangular fissure closed towards the apex by an external convex pseudo-deltidium; beneath which, and diverging from it, is another transverse plate connecting the vertical dental lamellse arched above, and beneath giving off a couple of median parallel lamellæ which are incurved so as to nearly join their inferior edges, thus forming a slitbearing tube, which projects beyond the limits of the plate from which it originates into the interior of the shell. A low median ridge extends from the beak to the anterior part of the valve; dorsal valve depressed, without area, with a distinct mesial fold." But in order that the characters of the genus should be better understood, I have figured in Pl. XIV. five drawings of Syringothyris typa, for which I am indebted to Professor Winchell himself. Now, it has been asked by Mr. Meek whether there may not occur at Millecent in Ireland, and elsewhere, two closely similar but really very distinct British types, confounded under the single specific denomination of Sp. cuspidata?-that is, one with a punctate structure, and another without it ; and the examination of this question by Dr. Carpenter has led him fully to adopt Mr. Meek's conclusion, as I shall presently explain.

Professor Winchell seems not to have been aware that the characters assigned by him to his genus had been already illustrated and defined by Professor L. de Koninck in the Transactions of the - Royal Society of Liege for 1859 ; and, as I made at the time some better and enlarged drawings from the Belgian specimens, I will reproduce them here along with $M$. de Koninck's original figure (PI. XIV. Figs. 6-9). These characters were found to exist in a Belgian example of the Carboniferous Spirifera distans. Professor Winchell adds: "Some difficulty exists in deciding on the homology of the transverse plate and fissured tube which characterize this genus (Syringothyris). In the ventral valve of Merista, especially of the type of Camarium Hall, an arching lamella arises from the basal pertion of each dental plate, and the two unite in the mesial line of the valve, forming a structure which Professor King, before the separation of this genus, had styled the shoe-lifter process-arched in front and attached to the bottom of the valve behind. In Spirifera granulifera Hall, a horizontal tranverse plate stretches across the middle of the beak of the ventral valve, connecting the dental lamelløe where nearest approximated by their inward curvatures-a structure which probably represents the pseudodeltidium of certain Spirifera, but not of Cyrtia. Beneath this plate, the ventral medium septum assumes the form of a tapering cone, resting with its base filling the cavity, and having the anterior part of the upper side marked by a longitudinal groove or slit, while the posterior part sends up a small vertical plate to the transverse plate just mentioned. In Syringothyris the tranverse plate equally connects the dental lamellæe where most approximated, and is somewhat arched upwards as in Merista, but it does not join the bottom of the 
valve as in that genus, nor is it connected with the median septum as in Spirifera granulifera. Nevertheless, it would seem that the three structures are modifications of the same elements."

But what is the element thus modified? Prof. King suggested that the shoe-lifter process of Cleiothyris concentrica is a modified form of the ventral median plate; but the wide separation of its points of origin from the normal position of this plate seems incompatible with such a conclusion; while in Syringothyris and Spirifera granulifera the median plate exists independently of the apparent homologue of the shoe-lifter. Mr. Billings, whose observations are generally marked by extreme sagacity, regards the shoe-lifter " as an abnormal form of the pseudo-deltidium that occurs in some Spirifers." This is the relationship pointed out above; and there seem to exist good morphological reasons for regarding the fistuliferous arching plate of Syringothyris as a modified pseudo-deltidium. But to what does the latter structure appertain? In Merista, Syringothyris, and-certain Spirifere its relation to the dental plates suggests that it may be an out-growth of those parts. The dental plates are amongst the most heteromorphous structures of the ventral valve. From a normal erect position, they become approximated along the ventral margins in many Spiriferce and other genera, while in Pentamerus, Orthisina, and Camaraphoria, this approximation results in complete union, and in Ireptana in the formation of the saucer-shaped process of the ventral valve. They also vary excessively in longitudinal development. In many Spirifera, moreover, there is an evident indication of a longitudinal folding of the dental-plates, producing on one side or the other a longitudinal laminar process, which, under an extraordinary development, may coalesce with some neighbouring part. While, therefore, the shoe-lifter process of Merista, and still more the fistuliferous diaphragm of Syringothyris, may be but modifications of the false inner deltidium of Spirifera granulifera, the three structures, accidental among Palliobranchs, may be but mere outgrowths of the essential and typical parts known as dental plates."

Such is Professor Winchell's description of his genus Syringothyris, and it would be very desirable if any gentlemen who possess good examples of $S p$. cuspidatus would eut some of them as shown in Fig. 11 of our Plate, so as to see how far they may agree or differ from Syringothyris.

I would also refer the reader to some extremely interesting observations upon this subject recently published by Professor J. Hall, in vol. iv. pp. 252-257 of his Palæontology of New York, and from which I will here give the following extract. "If again we look at the characters of Spirifera alta, an analogue or representative of Spirifera cuspidata, we have many points of similarity with one or more species in the rocks of the west and south-west (America) which are usually referred to a higher position, The high area, and the tranverse concave septum, which is not a true pseudo-deltidium, allies it with Sp. textus, in which we find similar features. In Sp. alta there has, probably, been an external convex pseudo-deltidium, and between this and the septum closing the fissure, there has been a 
narrow space. This septum, which is an extension of the dental lamellæ, has been thickened or expanded in the inner side, as shown by casts of the ventral valve, and in several specimens there is a narrow semi-cylindrical depression extending nearly to the beak of the valve. In comparing this with Sp. textus, we find similar conditions, or more properly an extension or amplification of the same features. In that species there is a convex arching pseudodeltidium, though rarely preserved in the specinens; beneath this there is a concave septum, and upon the inner face of this there is a tubular callosity ; or, in other words, the inner laminæ of the septum become fistulose, and enclose a cylindrical or sub-cylindrical space, which extends from the base of the septum to near the apex of the valve. But more usually the laminæ appear to be separated, and, extending inwards, are recurved, their edges sometimes joining to form a tube, but more frequently, perhaps, the margin of each one is recurved upon itself, leaving the tube with a slit along the lower side. In some instances, however, these extensions from the inner face of the septum continue to the bottom of the cavity, and, joining the external shell, leave a quadrangular tube instead of a cylindrical one.

"If, in its full development, the presence of a septum and internal tube be regarded as of generic value, then we have in Sp. alta the same appendages in part, or in a partially developed condition, the distinct tube only being wanting. But had we the means of examining the interual characters of the ventral valves of all the species of Spirifers, we should, probably, find graduations from the solid filling of the rostral cavity, with a greater or less extension of shelly matter in the form of a septum, in the fissure occupying a narrow space in its apex, till we reached the development observed in $S$. alta and $S$. textus, etc." It is, therefore, quite evident that much more investigation with reference to the shell-structure of Spirifers, as well as to their interior arrangements, will be required before they can be all definitely divided into groups or genera. After a minute examination of several specimens of Spirifer, agreeing in shape with Sp. cuspidata, and occurring at Millecent in Ireland, Dr. Carpenter has found that in one example the entire shell was unquestionably imperforate, while in others from the same locality certain parts are unmistakeably perforated, although large patches remain free; and that in these last named shells, as seen in Fig. 11, the two dental plates or lamellø are connected by a transverse plate, under which is situated an incomplete tube, similar to the one described by Professor Winchell as peculiar to his genus Syringothyris. In the imperforate specinen, on the other hand, he finds the dental lamellæ to be unconnected by any transverse plate, and the tube of Syringothyris to be altogether absent.

The next point alluded to by Professor King has reference to the Cyrtina heteroclita. It is quite true that in the Annals and Mag. of Nat. Hist. for August, 1846 (not 1864) Professor King did describe the septa and dental plates in this species, and did also announce that the valves were distinctly perforated, and I much regret having inadvertently omitted to state this in my Monograph, 
and for which omission I gladly apologise; but at the same time it is also right to add that as early as 1841 both Mr. Bouchard and myself were well acquainted with the internal characters of the ventral valve of this species, as well as of $C$. Demarlii, for we had found specimens showing the position of the septum and dental plates in an excellent state of preservation in the Devonian quarries of Ferques in the Boulonnais, and it was from those specimens that the figures given in my Monograph were drawn. I was not, consequently, indebted to Professor King for the information I possessed upon this subject; but am exceedingly glad to learn that he has discovered vestiges of spiral coils in Cyrtina heteroclita, as I had not hitherto been so fortunate as to see them in any of the many specimens of the species I had obtained. I may also here repeat that I still adhere to the opinion expressed in my Monograph, namely, that, until sufficient proof to the contrary can be adduced, I must continue to consider C. carbonaria and C. septosa, as referable to the same group as that typified by $C$. heteroclita and $C$. Demarlii, and that they apparently all possess a perforated shell-structure.

\section{EXPLANaTION OF PLATE XIV.}

Figs. 1-5. Syringothyris typa, from drawings communicated by Professor Winchell.

1. Dorsal valve (cast). 2. p. dorsal, v. ventral valves, $l$. line indicating the length and position of the dental plates. 3. Dorsal and part of the ventral valve seen in profile. 4. Beak of ventral valve partly destroyed; $a$. area, $b$. dental plates or lamellæ, $t$. tube incomplete, $r$. mesial ridge. 5. Section through A.B. The same letters refer to same parts.

Figs. 6-9. Syringothyris? distans, Sow., from the Carboniferous limestone of Visé, in Belgium. 6. Part of the beak of ventral valve, seen from the back, and after Professor L. de Koninck's original figure, published in 1859. $7,8,9$. My drawings from the same specimen, enlarged. 7. Area and pesudo-deltidium. 8. The same viewed from the opposite side, the shell forming the back of the ventral valve being removed so as to show the shape and position of the dental plates, as well as the position of the transverse plate and tube. 9 . The same seon in front; the area and pesudo-deltidium being foreshortened.

Fig. 10. Syringothyris cuspidata, or typa? from Millecent, Ireland.

Fig. 11. " ", from same locality. A transverse section of the "beak having been cut through by Dr. Carpenter to show the position of the dental plates, transverse plate, and incomplete tube, as seen in the American specimens of Syringothyris typa. In this specimen portions of the shell were perforated, while other parts were free. Indications of the spiral coils may here also be perceived.

\section{NOTICES OF MEIMOIRS.}

I. - ON the Punotate Shell-structure of Syringothiris. By F. B. MatK, (from Silliman's American Journal of Science and Arts, May, 1867, p. 407).

A AVING recently examined Professor Winchell's types of his genus Syringothyris, which he was so kind as to loan me, I find them all, with the exception of two silicified specimens (showing no structure), distinctly punctate. It is probable that Professor Winchell had hap- 